\title{
Out With the Thatch and In With the Shingles: An Examination of Assimilation into Canadian Society, as Demonstrated by the Homes of the First Ukrainian Settlers
}

\author{
Miranda Koshelek
}

\begin{abstract}
The concept of 'the Canadian identity' is a topic which has received much attention in recent decades, stimulating discussions on the topic of what makes a Canadian a Canadian? Today, being Canadian might suggest a love of hockey and poutine. However, a century ago, being "Canadian" was an emphasis on adapting or conforming to British norms. This paper will focus on one important theme in debates around 'Canadianization', specifically its reflection over time in the domestic structure of the early Ukrainian settlers. Canadian identity studies can especially benefit from this trace of identity formation, by its application to a broader, multi-ethnical context.
\end{abstract}

\section{Introduction}

When the first Ukrainian settlers arrived in Canada, the possessions they brought with them were minimal: the odd bauble of sentimental value, the occasional holy icon, bags of seed, and even metal tools. The settlers also brought with them the knowledge of their home. ${ }^{1}$ Their former homeland taught them the skills necessary to survive in the sometimes harsh land of the Canadian prairies, skills which often were based on a foundation of economy. Historian John-Paul Himka writes, "the pioneering skills which served the Ukrainian community so well were essentially the skills... that enabled them to feed, clothe, and house themselves with little or no money." 2 The ability and manner in which Ukrainian settlers housed themselves provides an interesting opportunity to examine domicile housing and its reflection of assimilation into Canadian society. The purpose of this paper is to analyze the three levels of Ukrainian settler housing: the burdei or sod hut, the khata or clay house, and the Ukrainian-Canadian home. Each style reflects a level of assimilation into AngloCanadian society, from minimal influence to overwhelming 'Canadianization'. Initially the settlers built homes that reflected the knowledge of the old country: their homes were made of materials immediately available to them on their newly acquired land, and were indistinguishable from the houses found in Ukraine at the same time period (at least externally). Eventually Ukrainian-Canadian homes would reflect the influence of AngloCanadian culture and be practically indistinguishable from their English neighbors.

\footnotetext{
1 Roman Onufrijchuk "Immigration and Organized Forgetting: Continuity and Change in Systems of Meaning," in Continuity and Change: The Cultural Life of Alberta's First Ukrainians, ed. Manoly R. Lupul (Edmonton: Canadian Institute of Ukrainian Studies, 1988), 4.

2 John-Paul Himka, "Cultural Life in the Awakening Village in Western Ukraine," in Continuity and Change: The Cultural Life of Alberta's First Ukrainians, ed. Manoly R. Lupul (Edmonton: Canadian Institute of Ukrainian Studies, 1988), 19.
} 
Ukrainian settlers emigrated from the provinces of Galicia and Bukovina, which were located in Austria-Hungary during the later nineteenth century. The land was fertile, albeit densely populated. Large landowners owned the majority of land, a lingering effect of serfdom. The average Ukrainian had very little land; most possessed under 5 hectares (approximately 12 acres), despite the fact that 5 hectares was considered the minimum required to support a family. ${ }^{3}$ Family plots were divided only among sons, and with each passing generation the land would be split into smaller parcels, eventually offering very little to future generations. At the same time, Canada was rumored to be offering 160 acres of free land to all men over the age of 18 . This potentiality was too appealing to ignore. Ivan Pylypiw, the first Ukrainian to come to Canada, discovered that the rumors were indeed true: the land was free (with some conditions, of course)! After this, it was only a matter of time before Ukrainian settlers came to Canada in large waves; approximately 170000 are estimated to have come by $1914 .{ }^{5}$ Ukrainian settlers primarily settled in the Canadian prairie provinces: Manitoba, Saskatchewan, and Alberta. For the purposes of this paper, I will focus on the Ukrainian settlers who settled in Alberta.

The trip overseas was an expensive one; in some cases a man might travel alone to the new country (and send for his family once he had earned enough money), but often a family would embark on the trip together. In order to do this they would sell their land and meager possessions in order to secure the fare. ${ }^{6}$ Once in Canada, the Ukrainians followed a gravitational pattern of settlement, meaning that they typically chose to settle near people from the old country. ${ }^{7}$ The area where they settled in Alberta today is known as the Ukrainian Bloc Settlement and is located in east central Alberta. ${ }^{8}$ Heavily wooded and sparsely populated, the land was immediately prized by the settlers for its abundant timber and open spaces. These two factors combined were crucial contributors to the 'Canadianization' of Ukrainian building practices.

\section{The Burdei}

The first home the Ukrainian settler would build on his land would be a sod hut, known as a burdei or buda. ${ }^{9}$ The home could be made entirely of resources obtained from the land and as a result was very inexpensive and relatively simple to construct. Timber was cut down from

\footnotetext{
3 Orest T. Martynowych, Ukrainians in Canada: The Formative Period, 1891-1925 (Edmonton: Canadian Institute of Ukrainian Studies Press, 1991), 8.

${ }^{4}$ It is debated whether or not Pylypiw was actually the first Ukrainian to come to Canada, though he is often hailed as such. Ivan Pylypiw, "How We Came to Canada" in Land of Pain, Land of Promise: First Person Accounts by Ukrainian Pioneers 1891-1914, trans. Harry Piniuta (Saskatoon: Western Producer Prairie Books, 1978), 27.

5 Frances Swyripa, Wedded to the Cause: Ukrainian-Canadian Women and Ethnic Identity, 1891-1991 (Toronto: University of Toronto Press, 1993), 4.

${ }^{6}$ William Czumer, Recollections About the Life of the First Ukrainian Settlers in Canada (Edmonton: Institute of Ukrainian Studies, 1981), 35.

7 Orest T. Martynowych, "Ukrainian Bloc Settlement in East Central Alberta, 1890-1930," in Continuity and Change: The Cultural Life of Alberta's First Ukrainians, ed. Manoly R. Lupul (Edmonton: Canadian Institute of Ukrainian Studies, 1988), 40.

8 This area stretches approximately from Edna-Star to Slawa (West to East), and from Smoky Lake to Vegreville (North to South). Martynowych, "Ukrainian Bloc Settlement in East Central Alberta, 1890-1930", 30.

9 Andriy Nahachewsky, “The First Imprint: The Burdei in the Wilderness," in Continuity and Change: The Cultural Life of Alberta's First Ukrainians, ed. Manoly R. Lupul (Edmonton: Canadian Institute of Ukrainian Studies, 1988), 78.
} 
the forest and leant together to create an inverted ' $v$ ' shape. ${ }^{10}$ The advantage of the ' $\mathrm{v}$ ' shape was that it prevented weakening of the structure. Rain and snow rolled off the roof rather than accumulating on top. Clay was used to fill the cracks between the logs and sod was piled on top. The floor of the burdei likely consisted of compacted soil with a clay wash on top. A clay stove or pich might be found in the corner, providing a means of heating the small structure. ${ }^{11}$

The inside decorations of the home represented the land where the Ukrainians came from; it was not filled with the conveniences of North America, but instead reflected the economy of the settler. Based on his informants, historian Andriy Nahachewsky is able to provide estimates of the Ukrainian settler's material possessions in a burdei. ${ }^{12}$ As much as $60 \%$ of their possessions were brought from the old country, 20\% were made from the land, and the remaining 20\% were purchased in Canada (mostly foodstuff). From these numbers, we can discern that the settlers had little opportunity to benefit from British innovation. Furthermore, these numbers suggest the level old world practices predominant throughout the dwelling.

As a result, a visitor to their burdei might encounter a trunk or skrynia brought from the old country filled with hand-made linen trousers and tops. There might also be a sheepskin vest or coat for the cooler weather. Many settlers also brought their grain-grinding stone with them because they were unsure if they would be able to procure one in the new land. ${ }^{13}$ The stone would be set in a frame of Alberta wood and once again used to grind the grain into flour for baking. The idea of bringing grain to the mill to be ground was considered a needless expense, in the same manner that purchasing white flour might be considered ostentatious. ${ }^{14}$ The burdei would likely also exhibit the deeply religious nature of the settlers with an icon hanging on the wall, one of the few decorations within the home.

Living in a burdei was hardly acceptable, but the desire to build up a farm and earn money was a greater priority compared to building a more permanent structure. ${ }^{15}$ As a result, dwellers had to contend with the large amount of insects, vermin, and reptiles, as well as the tendency for leakage in the rainy season. If the sod became too wet, water would seep through and cause quite the muddy puddle within. ${ }^{16}$ Regardless, a sod house could easily last for as many years as required, so long as it was properly constructed and preserved.

However, nearly all settlers built a more permanent structure as soon as they were able. This was done in order to fulfill the requirements of the Dominion Land Act, which required settlers to build a house on their land valued at $\$ 300 .{ }^{17}$ The burdei could not fulfill this

\footnotetext{
10 Jaroslav Petryshyn, Peasants in the Promised Land: Canada and the Ukrainians, 1891-1914 (Toronto: James Lorimer \& Company, 1985), 76.

11 Martynowych, Ukrainians in Canada, 80.

12 Nahachewsky, “The First Imprint”, 81-83.

13 Onufrijchuk, "Immigration and Organized Forgetting," 4.

14 Petryshyn, Peasants in the Promised Land, 75.

15 Nahachewsky, "The First Imprint", 78.

16 Swyripa, Wedded to the Cause, 222.

17 Alberta Online Encyclopedia "Ukrainian Log Home"

http://culture.alberta.ca/archives/educationalresources/homestead/hs1.aspx
} 
requirement, and as such, a more permanent structure, a two-roomed khata, was constructed. ${ }^{18}$

\section{The Kbata}

The khata was the standard dwelling of Ukrainian peasantry in eastern Austria-Hungary. Although its construction might vary depending on the region and materials available, the structure typically followed a pattern which Ukrainian settlers emulated in Alberta. The point of khata construction is where the Ukrainian settlers began to differ from their old world counterparts. In Austria-Hungary, peasants would construct additional rooms onto their khata as a place to keep animals and grain, in an attempt to compensate for the lack of land to build a granary and barn. However, in Alberta, the 160 acres allowed for a khata to be built exclusively for human living and outbuildings could be built as needed to fulfill farming needs. The yards of the homesteaders resembled the style of the wealthy landowner in the old country, rather than the peasant class from which they had departed. ${ }^{19}$

The construction of the khata was very efficient and cost-effective, and provided a much larger living area for the settler. Typically the home would be constructed from a rough frame of horizontal logs placed on top of one another. A mixture of clay and straw would be filled between the cracks and heavily layered on either side of the logs to provide substantial insulation. ${ }^{20}$ Some farmers chose to whitewash the walls of their home, though some did not. Although traditionally (and usually initially) the roof would be constructed out of thatch, Ukrainian settlers soon learned the value of readily available wood shingles. ${ }^{21}$ Shingles were less flammable than the thatch, required less maintenance once installed, and were available at an affordable price. The appearance of the roof also changed with the addition of a chimney, a feature that was not often included in the old country. ${ }^{22}$ The floor was another aspect that soon changed due to the influence of the Albertan market. Although the floor originally consisted of clay with himniak on top (a mixture of cow manure, clay, and water), the Ukrainians soon saw the benefit of milled wood instead. The clay himniak was effective for keeping the dust down, but it required frequent upkeep, and wood simply became preferable. $^{23}$

The standard design of a khata had one large room, called the mala khata (literally 'small house'), which contained the areas for all basic day-to-day living. The Ukrainian settlers did not develop the same ideas of 'personal space' as we have today, and as a result whole families lived together in a common space. A mala khata contained a bed for sleeping, a table for eating, benches to sit on, cupboards for storage, a variety of pails for water and slop, and lastly a stove. Traditionally, like in the burdei, Ukrainians would have a clay oven inside their homes to do all their cooking. However, with the introduction of the 'Canadian

\footnotetext{
18 Martynowych, “Ukrainian Bloc Settlement in East Central Alberta, 1890-1930”, 33.

19 Radomir Bilash, "Ukrainian Rural Communities in East Central Alberta Before 1930," in Continuity and Change: The Cultural Life of Alberta's First Ukrainians, ed. Manoly R. Lupul (Edmonton: Canadian Institute of Ukrainian Studies, 1988), 65.

${ }^{20}$ Czumer, Recollections, 44.

${ }^{21}$ John C. Lehr, "The Cultural Importance of Vernacular Architecture," in Continuity and Change: The Cultural Life of Alberta's First Ukrainians, ed. Manoly R. Lupul (Edmonton: Canadian Institute of Ukrainian Studies, 1988), 92.

22 "Ukrainian Log Home."

23 Petryshyn, Peasants in the Promised Land, 76-77.
} 
stove', many people soon purchased a wood-burning stove for their home. Although a large purchase, many people could afford such a modern amenity soon after their first few harvests. ${ }^{24}$ The stove had many advantages over the clay oven: it required relatively little time to heat when compared to the pich, it occupied considerably less space, and it was an effective method of heating the khata. However, the oven of the Canadian stove was very small compared to the size of the pich, and for this reason, many Ukrainian women decided to continue the use of their pich, although generally just for the baking of the weekly bread. In some cases, a pich was built in a khata before a stove was purchased. In such situations, the pich would remain indoors beside the new stove. However it was soon discovered that the large amount of heat the pich released was bothersome in the summer, and it was preferable to build it outside. Eventually, many Ukrainians had a pich outside their khata and a 'modern' stove within.

A second room might be added to the khata, the velyka khata (literally 'big house'). In this phase of dwelling construction, the Ukrainian settlers would rarely make use of the room, a practice reflective of old country mentality. It was generally kept for 'special occasion' use; the velyka khata garnered the nickname 'celebration room'. ${ }^{25}$ Its importance is evident in the high level of decoration and quality of furniture within. In some cases, the velyka khata might be the first of the two rooms to receive wood floors, despite it receiving the least traffic. When not in use for a feast day (though feast days were fairly common; in most months at least one was celebrated), it was kept as a place for storage. The velyka khata still retained elements of the old country: holy icons could be seen placed on the East wall, a kilim (a tapestry or weaving) might be found on the north wall (which served as an attempt to block out the cold northern wind), and other weavings might be found to decorate the room in the form of the nalavnyk and zalavnyk (literally 'on bench' and 'behind bench'), especially as weaving still occupied a large part of the Ukrainian woman's life. There might also be a skrynia in the velyka khata, a place to store the traditional clothing of the culture. This was because many men and women at this point were dressing in the fashions of British-Canadians, but still keeping their traditional clothing to wear on Sundays and holidays.

\section{The Ukrainian-Canadian Home}

The final phase of dwelling construction is what can be called the Ukrainian-Canadian home. This stage marked the integration into Canadian society, as the dwellings differed greatly from those of the old country. ${ }^{26}$ However, the houses still retained a few key traditional aspects, which were an effective integration of Ukrainian culture into Canadian society. ${ }^{27}$ Not every settler who came prior to World War I would live in such a home, because the level of assimilation varied. Often, the quality of land (and the amount of capital to be made off of it) determined the amount of time it took for the settlers to upgrade from the khata. The minimal amount of time was five years. ${ }^{28}$ The number of years was generally much longer in areas with poor land quality.

\footnotetext{
24 "Ukrainian Log Home"

${ }_{25}$ Marie Lesoway, "Women In Three Households," in Continuity and Change: The Cultural Life of Alberta's First Ukrainians, ed. Manoly R. Lupul (Edmonton: Canadian Institute of Ukrainian Studies, 1988), 122

26 Martynowych, "Ukrainian Bloc Settlement in East Central Alberta, 1890-1930”, 35.

${ }^{27}$ Lehr, "The Cultural Importance of Vernacular Architecture", 95.

28 Martynowych, Ukrainians in Canada, 81.
} 
The Ukrainian-Canadian home closely resembled today's modern home, a structure consisting of several rooms. Numerous rooms now served and replaced the function of the mala khata and, most importantly, velyka khata. The advances in heating, such as the availability of central heating furnaces fueled with coal, effectively removed the functionality of a room based on its proximity to the stove. ${ }^{29}$ This effectively split the function of the mala khata into separate rooms. For example, sleeping was designated to private chambers, allowing space for parents in one room and children in another. Likewise, the room with the all-important stove became the kitchen. It remained the most functional room in the house, it was a room for preparing food, eating meals, and entertaining company. ${ }^{30}$

A special room would now be set aside to function as the velyka khata. Generally with Anglo-Canadian house plans, the dining room served this purpose. The room was still constructed with the finest materials, with manufactured flooring and paint on the walls, and the most important decorations. As Marie Lesoway explains, "these refinements reflected the influence of Canadian building conventions", but of course some aspects of tradition still remained. ${ }^{31} \mathrm{~A}$ wall might be decorated with fine wainscoting on the bottom, but the top might be brushed with traditional whitewash, which was so popular in the previous style of housing. Likewise, a floor might be painted yellow, perhaps reminiscent of the clay that once covered the ground. Icons were still hung on the east wall, but in addition, Canadian-style portraits and pictures might also decorate the other walls. ${ }^{32}$ Various weavings might still be found in the room, but to a lesser degree. By the stage of the Ukrainian-Canadian house, most women no longer maintained the skills of the old country, such as weaving (and to a lesser degree, embroidery) and had gotten rid of the loom. ${ }^{33}$ Instead, they possess a few pieces they had made in their youth or pieces their mothers or grandmothers might have made.

\section{Conclusion}

Housing transition is one way which traces the Ukrainian identity as it merged with Canadian identity to create a new Ukrainian-Canadian identity. From a sod hut to a multiple roomed home, Ukrainians came a long way in a few decades. There are a few crucial factors which ultimately caused the construction of the Ukrainian dwelling to divert from practiced and traditional methods to new and British-style housing. First and foremost, the possession of more land was the strongest factor. Owning over ten times the typical amount of land as in the old country, the settlers had the space to build larger houses and yards. Ukrainians were also in a position to grow more than what they required to live and were able to accumulate wealth. Second, the availability of natural resources led to the injection of an increase of wood products in the home. These included milled floors and wood shingles. Lastly, the exposure to Anglo-Canadian innovations and practices, as well as being in the financial position to take advantage of them, led to the addition of many previously-unknown conveniences. These included such items as stoves, store-bought clothing, and central heating. Each of these factors moulded the Ukrainian's housing style to reflect their level of assimilation into a country and culture far different from the land they had left behind.

${ }^{29}$ Lehr, "The Cultural Importance of Vernacular Architecture", 96.

${ }^{30}$ Lehr, "The Cultural Importance of Vernacular Architecture", 97.

31 Lesoway, "Women In Three Households", 122.

${ }^{32}$ Lehr, "The Cultural Importance of Vernacular Architecture", 96.

33 Lesoway, "Women In Three Households", 120. 


\section{Bibliography}

Alberta Online Encyclopedia "Ukrainian Log Home"

http://culture.alberta.ca/archives/educationalresources/homestead/hs1.aspx [accessed March 20, 2011]

Bilash, Radomir. "Ukrainian Rural Communities in East Central Alberta Before 1930." In Continuity and Change: The Cultural Life of Alberta's First Ukrainians, ed. Manoly R. Lupul, 60-76, Edmonton: Canadian Institute of Ukrainian Studies, 1988.

Czumer, William. Recollections About the Life of the First Ukrainian Settlers in Canada. Edmonton: Institute of Ukrainian Studies, 1981.

Himka, John-Paul. "Cultural Life in the Awakening Village in Western Ukraine.” In Continuity and Change: The Cultural Life of Alberta's First Ukrainians, ed. Manoly R. Lupul, 10-23. Edmonton: Canadian Institute of Ukrainian Studies, 1988.

Lehr, John C. "The Cultural Importance of Vernacular Architecture." In Continuity and Change: The Cultural Life of Alberta's First Ukrainians, ed. Manoly R. Lupul, 87-99. Edmonton: Canadian Institute of Ukrainian Studies, 1988.

Lesoway, Marie. "Women In Three Households." In Continuity and Change: The Cultural Life of Alberta's First Ukrainians, ed. Manoly R. Lupul, 114-120. Edmonton: Canadian Institute of Ukrainian Studies, 1988.

Martynowych, Orest T. "Ukrainian Bloc Settlement in East Central Alberta, 1890-1930." In Continuity and Change: The Cultural Life of Alberta's First Ukrainians, ed. Manoly R. Lupul, 30-59. Edmonton: Canadian Institute of Ukrainian Studies, 1988.

Martynowych, Orest T. Ukrainians in Canada: The Formative Period, 1891-1925. Edmonton: Canadian Institute of Ukrainian Studies Press, 1991.

Nahachewsky, Andriy. "The First Imprint: The Burdei in the Wilderness." In Continuity and Change: The Cultural Life of Alberta's First Ukrainians, ed. Manoly R. Lupul, 78-86. Edmonton: Canadian Institute of Ukrainian Studies, 1988.

Onufrijchuk, Roman. "Immigration and Organized Forgetting: Continuity and Change in Systems of Meaning." In Continuity and Change: The Cultural Life of Alberta's First Ukrainians, ed. Manoly R. Lupul, 2-8. Edmonton: Canadian Institute of Ukrainian Studies, 1988.

Pylypiw, Ivan. "How We Came to Canada." In Land of Pain, Land of Promise: First Person Accounts by Ukrainian Pioneers 1891-1914, trans. Harry Piniuta, 27-35, Saskatoon: Western Producer Prairie Books, 1978.

Petryshyn, Jaroslav. Peasants in the Promised Land: Canada and the Ukrainians, 1891-1914. Toronto: James Lorimer \& Company, 1985.

Swyripa, Frances. Wedded to the Cause: Ukrainian-Canadian Women and Ethnic Identity, 1891-1991. Toronto: University of Toronto Press, 1993. 